\title{
Klinik Psikoloji Bağlamında Kadına Yönelik Aile İçi Şiddetin Değerlendirilmesi: Kadın, Çocuk ve Meslek Elemanlarının Psikolojisi Üzerine Bir Gözden Geçirme Çalışması
}

\author{
Evaluation of Domestic Violence against Women in the Context of Clinical \\ Psychology: A Review of the Psychology of Women, Children and the Professionals
}

\author{
Tuğba YILMAZ * \\ Cansu KARAKUŞ ${ }^{* *}$
}

Öz: Kadına yönelik aile içi şiddet ulusal ve uluslararası alan yazında çok boyutlu olarak incelenmekte olan bir travmatik (örseleyici) bir yaşantı ve bir halk sağlığı sorunudur. Bu alanda çalışmakta olan birçok meslek grubunun arasında psikologlar da yer almaktadır. Kadına yönelik aile içi şiddetin sınıflandırılması, yaygınlığının ve risk etmenlerinin belirlenmesi bu alanda yapılan çalışmaların güçlendirilmesine fayda gösterebilir. Bu alanda görev alan psikologlar ve diğer meslek elemanlarının risk altında olduğu ikincil travmatik stres, temsili (üstlenilmiş) travma, merhamet yorgunluğu ve mesleki tükenmişliğin ne olduğunun anlaşılması ve bu deneyimlerin nasıl geliştiğinin ele alınması meslek elemanlarının güçlendirilmesini ve olumsuz yaşantılara karşı korunmasını sağlayabilir. Kadına yönelik şiddetin kadın ve çocuklar üzerindeki etkilerinin araştırılması travma mağdurlarının hem fiziksel hem de psikolojik olarak nelerle karşılaştığının belirlenmesini amaçlamaktadır. Bu bilgilerin güncel halinin ele alınması, kadına yönelik aile içi şiddet alanındaki travma mağdurlarının ve bu alanda çalışan meslek gruplarının deneyimlerinin belirlenmesine, bu deneyimlerde ortaklıkların olup olmadığının değerlendirilmesine, tedavi ve destek çalışmalarında yapılabilecek müdahalelerin psikolojik boyutunun ele alınmasına katkıda bulunabilir. Bu çalışmada güncel ve ağırlıklı olarak Türkiye'de yapılan kadına yönelik aile içi şiddet konulu araştırmalar yukarıdaki başlıklar üzerinden tartışılmıştır. Çalışmada klinik psikoloji alanındaki kavram ve konular öncelikli olarak ele alınmaya çalışılmıştır.

Anahtar sözcükler: Kadına Yönelik Aile İçi Şiddet, Travma Sonrası Stress Bozukluğu, İkincil Travma

\begin{abstract}
Domestic violence against women is a traumatic experience and a public health problem which is studied multi-dimensionally in both national and international literature. Among the many occupational groups working in this field, there are psychologists. The classification, prevalence and risk factors in domestic violence against women may help strengthen the studies in this area. Understanding the secondary traumatic stress, vicarious trauma, compassion fatigue and occupational burnout in which psychologists and other professionals are at risk in this area and discussing how these experiences develop are elements that enable the strengthening of the professional staff and help to protect against negative experiences. The investigation of the effects of violence against women on women and children aims to determine what the victims of trauma physically and psychologically experience. This current review of studies may contribute to identifying the experiences of trauma victims in the domestic violence area and the professional groups working in the field, assessing whether they have common experiences from these experiences, and address the psychological aspects of interventions in treatment and support. In this study, current and primarily research on domestic violence against women in Turkey is discussed in respect to the topics mentioned above and the concepts and issues in the field of clinical psychology are studied.
\end{abstract}

Keywords: Domestic Violence Against Women, Post-Traumatic Stress Disorder, Secondary Trauma

\footnotetext{
* $\quad$ Dr. Öğr. Ü., İzmir Bakırçay Üniversitesi, Fen Edebiyat Fakültesi, Psikoloji Bölümü, İzmir. tugba.yilmaz@ bakircay.edu.tr, https://orcid.org/0000-0001-9187-7665

** Psk., Ankara Şiddet Önleme ve İzleme Merkezi, Ankara. cansu.karakus@ ailevecalisma.gov.tr, https://orcid.org/0000-0001-8186-9397
} 


\section{Şiddet Kavramı}

Şiddet günümüzde son derece dikkat çeken, gündelik yaşamda da yaygın olan bir insan hakları ihlalidir ve bir halk sorunudur (Dişsiz \& Hotun-Şahin 2008; Öztürk et al. 2016). Şiddet bireylerin ve toplumların fiziksel ve ruhsal sağlı̆̆ını, refahını ve iyi olma halini olumsuz etkiler. Farklı tanımları olan şiddet, genel anlamı ile Dünya Sağlık Örgütü tarafından şu şekilde ifade edilmiştir: "Fiziksel güç ya da kuvvetin, amaçlı bir şekilde kendine, başkasına, bir gruba ya da topluluğa karşı fiziksel zarara ya da fiziksel zararla sonuçlanma ihtimalini artırmasına, psikolojik zarara, ölüme, gelişim sorunlarına ya da yoksunluğa neden olacak şekilde tehdit edici biçimde ya da gerçekten kullanılmasıdır" (DSÖ; 2002, 4). Tanımı itibari ile şiddetin farklı şekilleri olabilir. Bunlar fiziksel şiddet, psikolojik şiddet, sözel şiddet ve ekonomik şiddet şeklinde sıralanabilir (Polat 2016).

Aile içi şiddet, partnerler ve ailedeki diğer bireyler arasında gerçekleşen genel itibari ile evde olan şiddet' olarak ifade edilebilir (Arın 1996). Her ne kadar aile içi şiddet ağırlıklı olarak aile içinde erkeğin kadına uyguladığ 1 şiddet şeklinde algılansa da (Zara-Page \& İnce 2008), ailenin diğer bireyleri arasında da geçiyor olabilir. Bu nedenle, bu çalışmada kadına karşı şiddet konusu işleneceği için, aile içi şiddet ifadesi yerine kadına yönelik aile içi şiddet ifadesi kullanılacaktır (Erden \& Akdur 2018). Kadına yönelik aile içi şiddet, günümüzde önemli bir sorun haline gelmiştir ve bu konuda hem sivil toplum kuruluşları hem de bakanlıklar gibi kamu kurumları bazı çalışmalar yürütmektedir. Bu konudaki akademik ve uygulamalı çalışmalar hukuk, tıp (Polat 2016), sağlık (Dişsiz \& Hotun-Şahin 2008, Öztürk et al. 2016) ve psikoloji (Zara-Page \& İnce 2008; Erden \& Akdur 2018) gibi birçok disiplin tarafından yürütülmektedir. $\mathrm{Bu}$ çalışma da kadına karşı aile içi şiddetle ilgili güncel araştırmaların derlenmesi, gözden geçirilmesi ve klinik psikoloji çerçevesinde değerlendirilmesi hedeflenmiştir.

\section{Kadına Yönelik Aile İçi Şiddetin Sınıflandırılması}

Dünya Sağlık Örgütü (2002) raporunda şiddeti üç sınıfa ayırmıştır. Birincisi kişinin kendine yönelik şiddeti; ikincisi kişiler arası şiddet ve üçüncüsü kolektif şiddettir. Aile içi şiddetin kişiler arası şiddet sınıfına girmesi gerekmektedir (Zara-Page \& İnce 2008). Şiddet çeşitleri açısından değerlendirildiğinde Yıldırım (1998) kadına yönelik aile içi şiddetin ihmal, duygusalpsikolojik şiddet, sözel şiddet, fiziksel şiddet ve cinsel şiddet şeklinde görülebileceğini ifade etmiştir. Buna göre, yeterli olmayan fiziksel ve duygusal ilgi gösterilmesi ihmal başlı̆g altında sinıflandırılır. Anlayış, sevgi görememe ve sempati duyulmaması gibi durumlar duygusal-psikolojik şiddet sınıfındadır. Tehdit, aşağılama, küçümseme, sindirme gibi davranışlar sözel şiddete girerken; itip kakma, dövme, yaralama gibi davranışlar fiziksel şiddet anlamına gelmektedir. Kadını cinsel ilişkiye istemediği mekanlarda, zamanda ve biçimde zorlama, çocuk doğurma ya da doğurmamaya zorlama, fuhuş yapmaya zorlama, cinsel yolla hastalık bulaştırma, ensest ve tecavüz gibi durumlar ise cinsel şiddet sınıfinda yer almaktadır.

$\mathrm{Bu}$ çeşitler değerlendirildiğinde, sözel ve duygusal-psikolojik şiddetin birbiriyle yakından ilintili olduğu dikkati çekmektedir. Duygusal ve psikolojik şiddet kadının eve kapatılması, ne giyeceğine karışılması, kimlerle görüşeceğine karışılması ve kimlerle görüşeceğinin kısıtlanması gibi bazı eylemleri içerebilirken, sözel şiddet eylem gerektirmeyen ancak duygusal ve psikolojik olarak kadına kötü hissettirmeyi kapsamaktadır. Örneğin kadına küfredilmesi ve aşağılanması sözel şiddet sinıfında değerlendirilirken, duygusal-psikolojik şiddet sinıfinda da değerlendirilebilir zira kötü sözler söylenmesi kişiyi psikolojik olarak şiddete uğramış hissettirir. Nitekim Öztürk ve arkadaşları (2016) çalışmasında sözel şiddetin kadının öz benliğinin yaralanmasına neden olabileceğini ileri sürmüştür. Sözel ve psikolojik şiddetin arasındaki farka işaret etmek için ise şu örnek ele alınabilir. Aile içi büyük kararlar alırken kadına danışmamak, duygusal şiddet olarak ele alınmaktadır. Bu örnek sözlü bir şiddet geçmediği için sözel şiddet 
sınıflandırması altına girmemektedir (Öztürk et al. 2016). Aralarındaki benzerlikten ötürü, Kadının Statüsü Genel Müdürlüğü (KSGM) 2008 ve 2013 yıllarına ait raporlarına göre kadına yönelik aile içi şiddetin çeşitlerinde duygusal şiddet sözel şiddeti de kapsamaktadır.

Yukarıda ifade edilen şiddet çeşitlerine ek olarak ekonomik şiddetten de bahsedilmesi önem arz etmektedir. Ekonomik şiddet genel itibari ile kadının ekonomik özgürlüğüne müdahale etmek olarak ifade edilmektedir. Kadının para harcamasının kısıtlanması, kadının parasının elinden alınması, kadının zorla çalıştırılması ya da çalışmasına izin verilmemesi, kadının iş bulmasını kolaylaştıran firsat ve etkinliklerin engellenmesi, kadının borca sokulması şeklinde örneklendirilebilir (KSGM 2008, 2013).

\section{Kadına Yönelik Aile İçi Şiddetin Yaygınlığı, Risk Etmenleri ve İstatistiki Veriler}

Kadına yönelik aile içi şiddetin yaygınlığ 1 konusunda uluslararası çalışmalardan en dikkat çekeni Dünya Sağlık Örgütü’nün 2005 yılı raporudur. Bu araştırma raporunda 10 farklı ülkedeki yaklaşık 24000 kadından yaşadıkları şiddeti rapor etmeleri istenmiştir. Buna göre, hayatlarının bir bölümünde kadınların eşleri tarafından fiziksel şiddete uğrama oranlarının \%13 ile $\% 61$, cinsel şiddete uğrama oranlarının $\% 6$ ile $\% 59$, duygusal şiddete uğrama oranlarının ise $\% 20$ ile $\% 75$ arasında değiştiği belirtilmiştir.

Ülkemizde ise yapılan çalışmalar arasında Altınay ve Arat'ın (2007) çalışması 56 ilde 1800 kadınla yürütülmüştür ve kadına yönelik aile içi şiddet konusunda çeşitli bilgiler sunmaktadır. $\mathrm{Bu}$ çalışma raporu T.C. Başbakanlık İnsan Hakları İnceleme Komisyonu'nun Kadın ve Aile Bireylerine Yönelik Şiddet İnceleme Raporunda (2011) da yer almıştır. Bu araştırmanın bulgularına göre her üç kadından biri eşinden fiziksel şiddet görmektedir. Bu kadınların yarısı şiddet gördüğü bilgisini kimse ile paylaşmamıştır. Okuma yazma bilmeyen kadınlar arasında en az bir kez fiziksel şiddet gördüğünü söyleyen kadın oranı \% 43 iken, yükseköğrenim görmüş kadınlarda bu oran \% 12'dir. Tanışıp anlaşan ve aile onayı alan çiftler, görücü usulü ile evlenen çiftler ve tanışıp anlaşan ve aile onayı almayan çiftlerde en az bir kez fiziksel güce dayanan şiddete maruz kalan kadınların oranı sırası ile yüzde 28, 37 ve 49'dur. Buna göre, evlilik şekli, evlenirken aileden onay alınmaması, öğrenim durumunun düşük olması, kadının erkekten daha fazla gelir elde etmesi, çocukken şiddete tanık olunması ya da maruz kalınması kadına yönelik aile içi şiddet için risk faktörleri olarak sıralanmaktadır. Bu çalışmada dikkati çeken çalışmaya katılan 10 kadından 9'unun erkeğin şiddetini haklı bulmaması ve şiddet uygulayan erkeğin ceza alması gerektiğini belirtmesidir (Altınay \& Arat 2007). Bu bulgular kadınların çeşitli oranlarda çeşitli türdeki aile içi şiddete maruz kaldığını göstermenin yanı sıra kadınların bu konuda farkındalık sahibi olduğuna, şiddeti meşrulaştırmadığına ve şiddetin bir yaptırım alması gereken eylem olduğuna inandığına işaret etmektedir.

Kadına yönelik aile içi şiddetin risk etmenleri Zara-Page ve İnce'nin (2008) derleme makalesinde incelenebilir. Bu çalışmaya göre, çocukluk çağında da aile içi şiddete maruz kalma ve tanık olma, sosyoekonomik ve sosyokültürel etkenler, yaş farkı, sosyal destek, dini etkenler, psikolojik etmenler şeklinde sıralanmaktadır. Benzer şekilde, erkek şiddetini anlamak açısından çocukluk çağında da aile içi şiddete maruz kalma ve tanık olma risk etmeni Altınay ve Arat (2007) çalışmasında da karşımıza çıkmaktadır. Saldırgan erkek açısından düşünüldüğünde bu kişinin, çocukluğunda ebeveynleri arasında gerçekleşen şiddete maruz kaldığ 1 ve şiddet uygulayan saldırgan baba ile özdeşim kurduğu için bu şekilde bir risk oluşturduğu söylenebilir (Vahip 2002). Bu aynı zamanda görerek öğrenme/model alma görüşü ile de açıklanabilir. Erkek çocuk sorunlarla baş etme yöntemi olarak şiddete başvurmayı öğrenmiş olabilir (Bandura 1978; Dorr \& Kovaric 1980).

Kadına yönelik aile içi şiddeti gerçekleştiren aktör erkek olduğu için erkeklerin şiddet göstermelerinin ardında bulunan nörobiyolojik etkenlerini araştıran çalışmalar incelendiğinde, kolinerjik ve katekolaminerjik sistemlerin saldırganlık seviyesini artırdığı; serotonerjik sistemle- 
rin ise saldırganlığı engellediği görülmektedir (Abay \& Tuğlu 2000). Hormonal seviyede testesteronun saldırganlıkla ilişkili olduğu hayvan çalışmalarında görülse de insanlarla yapılan çalışmalarda tutarlı ilişki görülmemektedir. Serotonin ile olan ilişkilerinden dolayı, glukoz, kortizol ve kolesterolün saldırganlıkla ilişkili olduğu bulgular arasındadır. Beyin yapısı anlamında amigdala, temporal lob ve limbik sistem alanları saldırganlığı etkilemektedir. Özellikle amigdala ve hipokampüsteki işlev bozukluğunun saldırganlık gösterilmesi arasında bir bağ bulunmuştur (Abay \& Tuğlu 2000; Eraslan \& Kayahan 2011; Yalçın \& Erdoğan 2013).

Sosyoekonomik ve sosyokültürel etmenler başlığı altında aile içi şiddetin işçi ve orta sınıf çiftlerde yaşandığı, erkeğin eğitim seviyesinin düşük olduğu, işsiz ya da iş yaşamında tutarsız olduğu durumlarla ilişkili olduğu belirtilmiştir. Altınay ve Arat'ın (2007) ve Yaman-Efe ve Ayvaz (2010) çalışmasına olduğu gibi, kadının eğitim seviyesinin, kariyer ve gelirinin erkekten yüksek olması da sosyokültürel risk etmenleri arasındadır. Bu durum erkeklerin gücünü sağlamlaştırmak ve cinsiyet eşitsizliğini sürdürmek amac1 ile aile içi şiddetin olduğu anlamına da gelmektedir (Taşdemir-Afşar 2016). Yaş farkı açısından yüksek risk, genç yaştaki kadınlarda daha fazladır. Aile ve sosyal çevreden alınan sosyal desteğin eksik olmasının aile içi şiddet yaşanması için risk etmeni olabileceği belirtilmiştir. Dini etkenler altında namus kültürüne ve namus cinayetlerine değinilmiştir. Psikolojik etmenler başlı̆g 1 altında evlilikte yaşanılan çatışmalarla başa çıkma becerilerinin zayıf olmasının yarattığı riskten bahsedilmektedir. Burada bir kez eşine karşı şiddet girişiminin olmasının, ileride şiddet yaşanma ihtimalini artırdığı ifade edilmektedir (bk. Zara-Page \& İnce 2008). Bütün bunlara ek olarak, kültürümüzde de görüldüğü gibi aile içerisinde ebeveynler tarafindan kız ve erkek çocuklarına yönelik ayrımcı birtakım gerçekleştirilen uygulamalar ve toplumsal cinsiyetçi yaklaşım stillerinin de şiddetin kuşaktan kuşağa geçmesinde önemli bir rolünün olduğu düşünülmektedir (Can 2014). Toplumsal yaşamda, kadının şiddeti "hak edecek" bir davranış sergilediğinde görebileceği, kadının namusunu korumak/laf getirtmemek için kadının yaşamına son verilebileceği, boşanmanın kabul görmediği, kadının namusunun/iffetinin korunması ile ilgili anlayışların aile içi şiddetin sürmesinde rol oynadığı öne sürülmektedir (Can 2014). Bu noktada Heise'nin (1998) ekolojik modelinden bahsetmek gerekmektedir. Bir sonraki bölümde bu konu tartışllacaktır.

\section{Ekolojik Model Tanımı ile Şiddet}

Heise (1998) cinsiyet temelli şiddeti açıklamak için ekolojik bir model önerisinde bulunmuştur. Hangi etmenlerin kadına yönelik şiddeti yordadığını ve bu etmenlerin hangi sosyal ekolojilerde gerçekleştiğini bu model üzerinde ifade etmiştir. Heise'ye (1998) kadına yönelik şiddetle ilgili risk etmenleri bireysel, durumsal ve sosyokültürel katmanlar bağlamında değerlendirilmelidir ve bu katmanların birbiri arasındaki etkileşimi göz önüne alınmalıdır. Ekolojik modele göre dört çeşit ekoloji bulunmaktadır. Bunlar; bireysel tarihçe, mikrosistem, eksosistem ve makrosistem şeklindedir.

Bireysel tarihçe ekolojisinde çocukken aile içi şiddete tanık olma, çocukken istismara uğramak, babanın yokluğu ya da babanın reddedici olması gibi özellikler sıralanmıştır. Mikrosistem içerisinde babanın aile içinde dominant olması, ailenin gelirinde babanın kontrol sahibi olması, alkol kullanımı, evlilikle ilgili ya da sözel çatışmalar yer almaktadır. Eksosistemde, yani bireyin birebir içinde olmadığı ancak bireyin içinde bulunduğu mikrosistemleri etkileyen sistemde ise düşük sosyoekonomik statü ya da işsizlik, kadının ya da ailenin yalnız kalması (sosyal desteğinin olmaması), suç işlemeye müsait akranlarla olan ilişkiler yer almaktadır. Son olarak makrosistem düzeyinde erkeğin kadın üstünde gücünün olmasının kabulü, agresyon ve dominasyonun erkeklikle ilişkilendirilmesi, sabit ve değişmez cinsiyet rolleri, kişiler arası şiddetin kabul görmesi ve fiziksel şiddetin (dayağın) kabul görmesi gibi sosyal normlar bulunmaktadır.

Birçok kültürde yapılan araştırmalara dayanarak önerilmiş olan bu ekolojik modeldeki risk 
etmenlerinin, bir önceki bölümde tartış1lan risk etmenlerini kapsadı̆̆ görülebilir. Heise'nin (1998) modeli bu ekolojilerin birbirleri içinde etkileşim kurduklarının altını çizmektedir. Makrosistem, eksosistemin özelliklerini şekillendirmekte ve mikro sistemler üzerinden bireyleri etkileyebilmektedir. Bu nedenle de kadına yönelik aile içi şiddetin açıklanmasına çok boyutlu bir bakış açısı sunmaktadır.

$\mathrm{Bu}$ risk etmenleri kadına yönelik aile içi şiddetin sosyal etmenlerden etkilendiği gibi kişilerin eylemleri üzerinde kişisel sorumluluk sahibi olduklarına da değinmektedir. Cinsiyet rolleri, saldırganlığın ve agresyonun erkeklikle ilişkilendirilmesi gibi toplumsal düzeyde kabul gören etmenler olduğu gibi bu etmenlere maruz kalan her erkek kadına yönelik aile içi şiddetle ilgili değildir. Aynı sosyal kabuller altında yaşayan erkeklerin de kişisel karar ve tercihleri bulunmaktadır. Bu karar ve tercihler erken dönem yaşantılardan etkilenmektedir. Özellikle çocukluk çağı istismarına maruz kalma ya da tanık olma gibi travmayla ilişkili bir boyutu dikkati çekmektedir (Altınay \& Arat 2007; Zara-Page \& İnce 2008). Bu husus klinik psikoloji kapsamında değerlendirilebilir. Psikopatolojik boyutta travma (örselenme) sonrası stres bozukluğu ölçütlerinde travma "gerçek ya da göz korkutucu bir biçimde ölümle, ağır yaralanmayla karşılaşmış ya da cinsel saldırıya uğramış olma" şeklinde ifade edilmiş olup doğrudan olayın yaşanması, başkasının başına gelen olaya tanıklık edilmesi, bir yakının başından olayın geçtiğinin öğrenilmesi, travmatik olayın olumsuz ayrıntılarına tekrarlı şekilde maruz kalma yolları ile yaşanabileceği ifade edilmiştir (Amerikan Psikiyatri Birliği 2014, 146). Aile içi şiddet bağlamında travmatik yaşantıdan ve travmanın geleceğe aktarımından bahsedilmesi bu bağlamda mümkün görünmektedir.

\section{Kadına Yönelik Şiddet Alanında Çalışan Meslek Elemanlarının Psikolojisi Hakkında}

Hassas topluluklara doğrudan hizmet vermekte olan meslek elemanlarının birlikte çalıştıkları kişilerden etkilendikleri düşünülmektedir. Araştırmalar son zamanlarda bu meslek elemanlarının ne gibi psikolojik süreçlerden geçtiklerini, nelere maruz kaldıklarını ve nasıl etkilendiklerini ele almaktadır (Newell \& MacNeil 2010; Gürdil-Birinci \& Erden 2016; Yanbolluoğlu 2019).

Kadına yönelik şiddet alanı gibi yıkıcı ve örseleyici olaylarla ilgilenen meslek elemanları arama kurtarma ekipleri, acil tıp teknisyenleri, acil servis çalışanları (hekim, hemşire ve diğerleri), psikolog, sosyolog ve sosyal hizmet uzmanları olarak sayılabilir. Bu meslek gruplarında görev alan kişilerin çalıştıkları kişilerin acılarını görmeleri, dinlemeleri ve paylaşmaları nedeni ile travmatik yaşantılardan etkilenebileceği belirtilmiştir (Rothschild \& Rand 2006). Bu meslek gruplarının yaşayabileceği duygusal ve psikolojik riskler temelde iki grupta ele alınmaktadır. Bu riskler travmayla ilişkili stres ve mesleki tükenmişlik olarak ifade edilmektedir (Newell \& MacNeil 2010). Travmayla ilişkili stres; ikincil travmatik stres, temsili travma (vicarious trauma), merhamet yorgunluğu gibi görünümlerle deneyimlenmektedir (Newell \& MacNeil 2010). Mesleki tükenmişlik travmaya maruz kalan ya da hassas gruplarla çalışan meslek gruplarına özgü bir durum değil iken (Maslach \& Jackson 1981); ikincil travmatik stres, temsili travma (vicarious trauma) ve merhamet yorgunluğu bahsi geçen meslek gruplarının zaman içinde yaşayabilecekleri deneyimler arasındadır (Gürdil-Birinci \& Erden 2016; Newell \& MacNeil 2010).

Mesleki tükenmişlik; duygusal tükenmişlik, depersonalizasyon ve profesyonel başarı algısının azalması olmak üzere üç faktör içeren çok yönlü bir kavramdır (Maslach et al. 2001; Newell \& MacNeil 2010). Duygusal tükenmişlik, çalıştıkları kişilerin devam eden talepleri ve ihtiyaçları karşısında bir psikoloğun duygusal kaynaklarının azalması iken; depersonalizasyon, iş arkadaşları, çalıştıkları kişiler ve yaşadıkları durumlara karşı psikologların kopuk ya da olumsuz davranışlar sergilemeleri şeklinde örneklendirilebilir. Son boyut olan profesyonel başarı algısının azalması, psikologların tedavi için çaba göstermelerine rağmen çalıştıkları kişilerin tedaviye yanıt vermemeleri ve psikologların kendini profesyonel anlamda yetersiz hissetmeleri 
şeklinde örneklendirilebilir (Maslach et al. 2001; Newell \& MacNeil 2010).

Kadına yönelik aile içi şiddet alanında çalışmakta olan psikologlar ve diğer meslek çalışanları, ikincil travmatik stres, temsili travma (vicarious trauma), merhamet yorgunluğu gibi yaşantılara yönelik risk taşıyabilirler. İkincil travmatik stres, merkezlere başvuruda bulunan şiddete maruz kalmış kadın ve çocuklarla çalışmaları sonucu psikologların travmatik yaşantılara dolaylı yoldan maruz kalması sonucunda oluşabilir ve TSSB belirtilerine benzer belirtileri yaşamalarına yol açabilir (Figley 1995; Bride 2007). Temsili travma (üstlenilmiş travma) ise psikologların kadına yönelik aile içi şiddet çalışmalarına devam etmeleri sonucunda bilişsel değişimler yaşaması anlamına gelmektedir. Bu bilişsel değişimlerin özelikle kontrol, güvenlik ve güven konusundaki algıları, düşünceleri ve inançları üzerinde olmaktadır (Pearlman \& Saakvitne 1995).

Travmayla ilişkili stresin üçüncü göstergesi merhamet yorgunluğu şeklinde olabilir (Figley 1995; Bride et al. 2007). Acı çekmekte olan kişilerle çalışan psikologların çok sıklıkla empati hissetmesi nedeni ile duygusal ve fiziksel yorgunluk hissetmeleri merhamet yorgunluğuna işaret etmektedir (Rothschild \& Rand 2006). Merhamet yorgunluğu, mesleki tükenmişlik gibi zamanla oluşmakta iken, temsili travma ve ikincil travmatik stres daha kısa süreli gelişmektedir (Newell \& MacNeil 2010). Merhamet yorgunluğu, zaman zaman ikincil travmatik stres ya da temsili travma kavramları yerine de kullanılmaktadır (Newell \& MacNeil 2010) benzer şekilde, ikincil travmatik stres ve temsili travma kavramları da birbirleri yerine kullanılmaktadır (Gürdil-Birinci \& Erden 2016).

Türkiye'de yapılan çalışmalar, travma alanında çalışan çeşitli meslek grupları örneklem alınarak gerçekleştirilmiştir. Gürdil-Birinci ve Erden (2016) çalışmasında psikolog, avukat, sosyal hizmet görevlisi ve ambulans görevlileri ile bir çalışma yürütmüş ve psikologların diğer meslek gruplarına kıyasla temsili travma (üstlenilmiş travma), ikincil travmatik stres ve tükenmişlik açısından daha az risk altında olduğu sonucu elde edilmiştir. Benzer şekilde, Zara ve İçöz (2015) çalışmasında meslek gruplarının riskleri açısından psikologların, psikiyatristler ve diğer meslek gruplarına göre daha az travmatik stres riski taşıdığı bulgusu elde edilmiştir. Bu çalışmada klinik psikoloji açısından önemli başka hususlar da ele alınmıştır. Örneğin, kadına yönelik aile içi şiddet alanında çalışan ruh sağlığı uzmanlarının süpervizyon almasının öneminin altı çizilmiş ve süpervizyonun psikologların travmatik stres yaşamaları konusunda koruyucu bir etken olduğu belirtilmiştir. Bu çalışma aynı zamanda ruh sağ lığ bir vurgu da bulunmaktadır. Bu vurgu travma alanında çalışan ruh sağlığı uzmanlarının çalışma saatleri üzerinedir. Çalışma saatleri uzun olan çalışanların travmatik stres düzeyleri az çalışanlara kıyasla daha azdır. Bu da travmayla ilişkin bilgilere ve travmaya maruz kalmış kişiye uzun ve yoğun şekilde maruz kalmanın ruh sağlı̆̆ çalışanlarının travmatik stres riskini artıracağına işaret etmektedir.

Çalışma deneyiminin de travmatik stres ile ilişkisi konusunda tutarsız bilgiler mevcuttur. Meslekte deneyim yılı ile travmatik stres yaşama düzeyi arasında ilişki olmadığı bulgusu Gürdil-Birinci ve Erden (2016) çalışmasında elde edilmiştir. Ancak, Yanbolluoğlu'nun (2019) çalışmasında incelenen diğer makalelere göre örnekleminde profesyoneller, gönüllü çalışanlar, polis memurları, ambulans ve acil servis çalışanlarının olduğu çalışmalarda deneyim yılı arttıkça travmatik stres yaşama düzeyi arasında bir ilişki görülmüştür. Bu bulgular deneyim yılı ve travmatik stres düzeyi arasındaki ilişkinin meslek grupları arasında farklılaşıyor olabileceği şeklinde yorumlanabilir. Meslek gruplarındaki bu farklılık alanyazındaki tutarsız bulguları açıklıyor olabilir.

Son olarak, psikologlar gibi ruh sağlığı alanında çalışanların travma mağdurları ile çalıştığ durumlardaki travmatik stres düzeylerini etkileyen önemli bir faktörün kişisel olarak travma yaşaması şeklinde olduğu dikkat çekmektedir. Türkiye'de gerçekleştirilen çalışmalarda bu bulgu 
tutarlı olarak karşımıza çıkmaktadır (Zara \& İçöz 2015; Gürdil-Birinci \& Erden 2016; Yanbolluoğlu 2019). Bu noktada, kadına yönelik aile içi şiddet riski etmenlerine geri dönmek ve aradaki paralelliğe bakmak gerekmektedir. Çocuklukta aile içi şiddete tanık olmanın ya da maruz kalmanın gelecekte bu tür şiddetin yaşanması açısında bir risk faktörü olduğu yukarıda tartışılmıştır (Altınay \& Arat 2007; Zara-Page \& İnce 2008). Kadına yönelik aile içi şiddet alanında çalışan ve destek, rehabilitasyon ve psikoterapi alanında hizmet veren ruh sağlı̆̆ uzmanlarının mesleklerini icra ederken travmatik stres yaşamalarında kişisel travma deneyiminin önemli bir risk faktörü olduğu da tartışılmıştır. Erken dönemde travmaya maruz kalmanın ne derece büyük bir hassasiyet yarattığının ve kesim fark etmeksizin ne derece bulaşıcı bir etkisi olduğunun dikkate alınması gerekmektedir.

\section{Kadına Yönelik Şiddetin Kadın Üzerindeki Etkileri}

Dünyada ve ülkemizde temel insan hakları ihlalleri ve sorunlarından biri olan 'kadına yönelik şiddet', kadınların vücut bütünlüğünü ve ruh sağlığını bozabilen, toplumsal, sosyal ve ekonomik statülerinin zarar görmesine veya kayıpla sonuçlanmasına yol açabilen toplum sorunudur. Farklı biçimlerde kendini gösteren şiddet olgusu; hem bireysel hem de toplumsal boyutta yaygın karşılaşılan bir kavram olarak karşımıza çıkmaktadır. Saldırganlık dürtüsünün şiddetin temelinde olduğu bilinirken, bu dürtünün toplumsallaşma süreci içerisinde öğrenilebildiği anlaşılmaktadır (Akkaş \& Uyanık 2016).

Şiddet türlerinden bir ya da birden fazlasına maruz kalan kadınların, bedensel, ruhsal ve sosyal açılardan olumsuz şekilde etkilenebildikleri, ancak şiddetin kadın üzerindeki etkilerinin yaşanılan şiddetin türüne, maruz kalma süresine, oluşturduğu riske, kadının sahip olduğu başa çıkma mekanizmalarına veya sahip olduğu sosyal desteğe göre farklılaştığı düşünülmektedir (Stewart \& Robinson 1998). Şiddete maruz kalan kadınların, şiddet karşısında verdikleri tepkilerin, şiddetin yaşanma biçimi ve süresine bağlı olarak değişebileceği de vurgulanmaktadır. Örneğin, eğitim düzeyi düşük olan ve ekonomik bağımsızlığa sahip olmayan kadınların, maruz kaldığ1 şiddete karşı evden ayrılmaya veya boşanmaya cesaret edemedikleri belirtilmektedir. Özellikle ailesi tarafindan sosyal veya manevi desteğe sahip olmayan şiddet mağduru kadınların, şiddet görme süresinin ailesinden sosyal destek alan şiddet mağduru kadınlara oranla daha fazla olduğu tespit edilmiştir (KSGM 2009).

Heise, Ellsberg ve Gottemoeller (1999) çalışmasında, şiddetin kadın üzerindeki etkilerini ölümcül olan ve ölümcül olmayan olarak iki kategoride tanımlamaktadır. Kadına yönelik şiddetin ölümcül olan etkileri kapsamında cinayete kurban gitme, intihar, bulaşıcı hastalıklar ve gebelikte anne ölümleri yer alırken, ölümcül olmayan etkilerinde ise fiziksel, ruhsal ve negatif sağlık davranışları yer almaktadır. Şiddete maruz kalmanın yol açtığı ölümcül olmayan sağlık problemlerinin başında fiziksel sağlık sorunları geldiği anlaşılmaktadır. Kadına yönelik şiddetin medikal birtakım sonuçlara neden olabildiği de yapılan araştırmaların bulguları arasında yer almaktadır. Fiziksel şiddete maruz kalan kadınların vücutlarının çeşitli bölgelerinde yaralar, morluklar, kırıklar, kronik ağrılar (mide, sırt, baş), kalıcı veya kalıcı olmayan sakatlıklar veya darbe sonucunda oluşan beyin hasarları oluşabildiği anlaşılmaktadır. Fiziksel şiddetin yanı sıra, cinsel şiddete maruz kalan kadınlarda istenmeyen gebelik, kürtaj, idrar yolu hastalıkları ve HIV/AIDS görünümleri ile bulaşıcı hastalıklar görülmektedir. Erkek şiddeti yaşayan kadınların strese bağlı olarak bedenlerinde ağrılar (baş ve sırt gibi bölgelerdeki ağrılar) (Stewart \& Robinson 1998), gastrointestinal sorunlar (AMACEJA 1989) yaşadıkları dikkat çekmektedir. Şiddete maruz kalan kadınların genel sağlık durumunun zaman içerisinde kötüye gittiği ve bir sağlık kuruluşuna başvurma oranlarının arttı̆̆ bilgisi de yapılan araştırmaların bulguları arasında yer almaktadır (Campbell et al. 1995; Yaman-Efe \& Ayaz 2010). Özellikle üreme çağında şiddete maruz kalan kadınların, sağlıklı geçirebileceği senelerinin tahminen \%5-\%16'sını kaybettikleri düşünülmektedir (Subaş1 \& Akın 2003). 
Kadına yönelik şiddetin etkileri ele alındığında, fiziksel etkiler ilk olarak düşünülse de, şiddetin psikolojik etkilerinden bahsedilmesi de oldukça önem arz etmektedir. Şiddete maruz kalan kadınların sıklıkla ruh sağlığı sorunları yaşadıkları yapılan pek çok araştırmada belirtilmektedir. Zara-Page ve İnce (2008) çalışmalarında, şiddete maruz kalmış kadınların \% 47.6'sının depresyon, \% 17.9'unun intihar riski, \% 63.8'inin travma sonrası stres bozukluğu, \% 18.5'inin alkol kullanımı, \%8.9'unun da madde kullanımı yaşadıkları belirtilmiştir. Yııldıım'ın (1998) çalışması, şiddete maruz kalmış toplam 112 kadınla yürütülmüştür. Bu araştırma raporunda, kadınların \% 45.5'inin klinik depresyon tanısı aldığı, \% 41.1'inin orta derecede depresyona sahip olduğu tespit edilmiştir. Yine aynı çalışmada, şiddete maruz kalmış kadınların \% 91.6'sının çocuğuna fiziksel şiddeti en az bir defa uyguladığı, çocuğuna şiddet uygulama sıklığının ise kadının sahip olduğu depresyon seviyesiyle doğru orantılı arttığı bilgisi mevcuttur.

Kang ve Kim'in (2011) çalışmasında, şiddet mağduru kadınların kaygı ve umutsuzluk hissedebildikleri, buna ek olarak, kontrol kaybı, benlik saygısı ve öz-yeterlilik inançlarında düşüş yaşayabildikleri belirtilmiştir. Gökkaya'nın (2009) çalışmasında, şiddet mağduru kadınların depresyon, uyku güçlükleri, yaşamdan zevk almama, sinirli ve gergin olma hali, adet düzensizlikleri vb. gibi sorunlar yaşayabildikleri belirtilmiştir. Bu bulgulara ek olarak, Mor Çatı Kadın Sığınağı Vakfı'nın 'Mor Çatı Deneyimi Kadına Yönelik Şiddete Dair Neler Anlatıyor? Kadına Yönelik Şiddet Değerlendirme’ raporunda, şiddete uğramış kadınların korku, suçluluk, yalnızlık, güçsüzlük hissedebildiği, başkasına güven duymakta güçlük çekme, kendini değersiz hissetme, sürekli tetikte olma halini yaşayabildikleri, endişeli, gergin olma, uyarıcılara karş1 kolay irkilme ve sürekli kötü bir şeylerin gerçekleşeceğine dair düşünceler taşıyabildiklerine değinilmiştir (Sakallı et al. 2017). Ayrıca, şiddet mağduru kadınların öfke patlamaları ve yeme bozukluklarına sahip olabildikleri, kendine zarar verme davranışlarının olabildiği belirtilmektedir. Nitekim, Heise ve arkadaşları (1999) çalışmasında, kadına yönelik şiddetin ölümcül olmayan etkileri kapsamında fiziksel ve ruhsal sağlık sorunlarının yanı sıra negatif sağlık davranışlarının yer aldığını da vurgulamıştır. Negatif sağlık davranışlarının içerisinde sigara, alkol ve madde kullanımının, cinsel risk alma davranışının sıklığının, fiziksel hareketsizliğin ve aşırı yeme davranışının bulunabildiğini ifade etmişlerdir. Öztürk ve arkadaşları (2016) çalışmalarında ise, şiddet mağduru kadınların toplum içerisinde adaptasyon açısından sıkıntılar yaşayabildiklerini, iş bulmakta zorlandıklarını veya sıklıkla iş yeri değiştirmek zorunda kaldıklarını ifade etmiş̧tir. Kadınların maruz kaldıkları şiddetin etkisi ile iş verimliliklerinin düşebildiğini, bunun da dolaylı ya da doğrudan ekonomik haklarından mahrum kalmalarına neden olabildiği belirtilmiştir. Ayrıca, şiddet mağduru kadınların işe geç kalma, yaptığı işe odaklanamama ve iş yerinde cinsel tacize uğrama gibi durumlar yaşayabildikleri de gözlemlenmiştir.

Ülkemizde yapılan çalışmalar arasında Güleç, Topaloğlu, Ünsal ve Altıntaş'ın (2012) çalışmasında, kadın konukevlerinde kalan kadınların geçmişinde de şiddete maruz kalma yaşantılarının olduğu görülmüştür. Ayrıca, bu kadınların şiddet davranışını kendi çocukları ile yaşadıkları ilişkilerde de deneyimledikleri saptanmıştır. Erken dönemdeki travmaların, baş etme becerilerini olumsuz etkileyerek özellikle problem çözme becerilerini azalttı̆̆ı yönünde bir tartışma sunmuşlardır. Şiddet mağduru kadınların bir problemle karşılaştıklarında; düşünerek, konuşarak, sabrederek ya da farklı seçenekleri deneyerek problemi ele alma eğilimlerinin zayıf olduğu belirtilmiştir (Güleç et al. 2012).

Travmanın olumsuz sonuçlarına rağmen, travma sonrası büyüme konusundaki çalışmaların kadına yönelik aile içi şiddet ortamındaki etkilerinin incelenmesi de önem taşımaktadır. Travma sonrası büyüme, travmatik bir olay sonrasında kişinin hayatla ilgili varsayımlarının ve güvenlik algısı gibi algılarının sarsılması sonrası bunların yeniden şekillenmesi, kişinin yeni anlamlar çıkararak travmayla başa çıkması olarak ifade edilmektedir (Karancı et al. 2012). Kadına yönelik aile içi şiddet mağdurları ile ülkemizde yapılan bir çalışma iyilik ve kontrol inancının 
travma sonrası büyümeyle ilişkili olduğunu ortaya koymuştur. İyilik inancı, dünyanın iyi bir yer olduğuna inanmak iken kontrol inancı gelecekte olacak olayların kişinin kontrolü altında olduğuna dair inanç olarak ele alınmıştır (Gökler-Danışman et al. 2018). Bu tür inançları yüksek olan kadınların, travmaları ile sağlıklı bir şekilde baş ettikleri, sarsılan algıları yerine anlamlı ve işlevsel algılar oluşturdukları ve travma sonrası günlük hayatta daha aktif ve işlevsel oldukları söylenebilir.

\section{Kadına Yönelik Şiddetin Çocuk Üzerindeki Etkileri}

Toplumsal bir sorun olan 'kadına yönelik şiddet' sadece şiddet mağduru olan kadını değil, varsa beraberindeki çocuklarını ve iletişimde bulunduğu kişileri de etkilemektedir. Aile içi şiddetin yaşandığı bir ailede, ebeveynler çocuklarının yaşanan şiddeti hissetmediklerini düşünebilir. Ancak çocuklarda dâhil olmak üzere, hane içerisinde yaşayan her bireyin bu şiddetin farkında olduğu ve şiddetten olumsuz etkilendiği düşünülmektedir (Lök et al. 2016). Bu kapsamda, kadına yönelik şiddet kavramının söz konusu sistemler dâhilinde değerlendirilmesi şiddet olgusunu ve etkilerini anlamak adına fazlasıyla önem teşkil etmektedir. Kadına yönelik şiddetin gelecekteki nesilleri dolaylı ya da doğrudan etkilediği yapılan pek çok araştırmada vurgulanmıştır. Bu bağlamda, çocuğu büyüten, ilk bakım veren kişinin annesi olduğu varsayıldığında, annenin çocuğun gelişiminde önemli bir etkisinin olduğu bilinmektedir. Bu sebeple şiddete maruz kalmış kadının fiziksel ve psikolojik mağduriyetinin çocuğunu da etkilediği düşünülmektedir (Geçikli \& Geçikli 2012). İlk bağlamda, şiddetin çocuk üzerindeki etkisi ele alındığında, bebek ile anne arasında oluşan bağın, anne karnında; doğumdan önce başladığı düşünülmektedir. Hamilelik boyunca özellikle fiziksel şiddete maruz kalan kadınların, madde ve sigara kullanımları arasında pozitif yönlü bir ilişkinin olabileceği veya düşük doğum ağırlığına sahip bebek dünyaya getirme ihtimallerinin artış gösterebileceği anlaşılmıştır (Campbell \& Lewandowski 1997). Newberger, Barkan, McCormick ve Yllove'un (1992) çalışmasında, hamilelik boyunca kadının uğradığı fiziksel şiddetin abdominal travma veya buna bağlı olarak plasentada doğrudan bir hasara neden olabildiği belirtilmektedir.

Özgentürk, Karğın ve Baltacı'nın (2012) çalışmasında, aile içi şiddetin hem şiddete maruz kalan çocuklar üzerinde hem de şiddete tanık olan çocuklar üzerinde birtakım etkiler oluşturabildiği ve bu etkilerin neden-sonuç ilişkisinin birbirinden ayrı olarak değerlendirilmesi gerektiği vurgulanmıştır. Bu bağlamda, yaşanılan aile içi şiddetin çocuğun hayat kalitesini düşürdüğü ve çocuğun geleceğe hazırlanmasını negatif yönde etkilediği belirtilmiştir. Alanyazında yapılan çalışmalar, kadına yönelik şiddet ile çocuğa yönelik şiddetin önemli ölçüde örtüştüğünü göstermektedir. Kadın konukevlerine görmüş olduğu şiddet nedeniyle başvuran kadınların \% 4070'inin çocuklarının da şiddete maruz kaldığı bilgisi mevcuttur (Kök-Can 2010).

Kadına yönelik şiddetin sadece kadınları etkilemediği, söz konusu durumun nesilden nesile geçebileceği yapılan pek çok araştırmada vurgulanmaktadır. Aile içi şiddet nesilden nesile geçmekte ve sadece şiddet mağduru olan kadını değil, aynı zamanda şiddete tanık olan kişilerin psikolojik durumlarını, özellikle çocukların psiko-sosyal gelişimini olumsuz yönde etkilediği düşünülmektedir. Çocuklar doğrudan şiddete maruz kalabilir veya şiddete tanık olabilirler (şiddeti görmek, duymak ya da sonrasında yaşananları gözlemlemek). Ev içerisinde şiddete tanık olmak veya şiddete maruz bırakılmak, çocuğun gelişmekte olan 'güvenli ve adil dünya' anlayışını zedeleyebildiği anlaşılmaktadır (Briere 1992). Travmatik olaya dolaylı ya da doğrudan maruz kaldıktan sonra çocuklar; dünyanın artık güvenli bir yer olmadığını, yetişkinlerin artık yeterli koruyucu olmadıklarını, olayların artık öngörülebilir veya kontrol edilebilir olmadığını düşünebilir (Janoff-Bulman 1992). Şiddete maruz kalan veya tanık olan çocuklar olaylar karşısında kendilerini suçlayabilir; 'koruyamadım, engelleyemedim', 'ben sebep oldum' vb., utanç ve suçluluk duygularını yoğun yaşayabilir (Stone 1992), düşük özgüven veya düşük öz yeterlik algısına sahip olabilir (Janoff-Bulman 1985; 1992). 
McGee'nin (2003) çalışmasında, Evason'dan aktardığı üzere, Evason'un yaptığı çalışmaya katılan kadınlardan \%72'si, kendilerinin maruz kaldığı şiddetten çocuklarının duygusal açıdan olumsuz etkilendiklerini aktarmışlardır. Alanyazında yapılan bazı araştırmalar, şiddet mağduru veya şiddete tanık olan anne ve çocukların, şiddetin kendi üzerlerinde pek çok olumsuz etkisinin olduğunu belirttiklerini aktarmıştır. Bu etkiler kapsamında korku, kızgınlık, öfke, üzüntü, depresyon, güçsüz hissetme, sosyal aktivitelerden çekinme vb. etmenleri içerdiği ifade edilmiştir (McGee 2003).

Çocukların öğrenme süreçlerinde taklit ve gözlemin önemli bir rolü vardır. Bu rol özellikle saldırganlık, kullanılan dil ve ahlaki davranışın gelişiminde kendisini gösterir. Örneğin annesinin babası tarafından şiddete maruz bırakıldığını fakat görmüş olduğu şiddetten sonra bir şey olmamış gibi aile yaşamlarına devam edildiğini gözlemleyen çocuk için baba güç sahibidir ve kontrol ondadır şeklinde bir algıya sahip olabilir. Çocuk ise şiddeti hem güç hem de kontrol kazandıran bir olgu olarak tanımlayabilir. Şiddet mağduru kadınların çocukları ile yapılan çalışmada, çocukların bilişsel bozulmalar, gelişimsel gecikmeler ve empati kurma seviyelerinin azalması gibi sorunlarla karşılaştıkları belirtilmiştir (Hilberman \& Munson 1978). Birtakım sosyal öğrenme kuramlarına göre çocuklar sosyal ortamlardaki davranışlarını belirlemek için yakınlarındaki insanları gözlemlerler. Gözlemleri sonucunda da bazı insanların davranışlarını taklit ederler (Özerkmen 2012). Daha sonra yapılan kontrollü çalışmalar, şiddete maruz kalan veya tanık olan çocuklar üzerinde şiddetin psikolojik veya fiziksel birtakım etkilere neden olabileceğini vurgulamıştır. Şiddetin çocuklar üzerindeki fiziksel etkileri kapsamında, şiddet esnasında yaralanmaları, arbedeye tanık olduklarında geçici veya kalıcı sakatlık yaşamaları, yetersiz beslenmeleri, sağlik kontrollerinin ihmal edilmesi gibi faktörlerden bahsedilebilir. Ayrıca, şiddet karşısında çocukların birtakım fiziksel belirtiler (baş ağrıları, altını ıslatma, uyku bölünmeleri, fiziksel büyümede gerilik, kusma, ishal) gösterebildikleri de vurgulanmıştır (Jaffe et al. 1986; Hughes 1986; Holden \& Ritchie 1991; Campbell \& Humphreys 1993; Attala et al. 1995).

Kadının Statüsü Genel Müdürlüğünden edinilen bilgilere göre, şiddetin çocuklar üzerinde oluşturduğu fiziksel etkilerin yanı sıra psikolojik birtakım etkilerinin de olduğu vurgulanmaktadır. Şiddet karşısında çocukların bilişsel veya duygusal tepkiler verebildikleri anlaşılmıştır. Örneğin, şiddete uğramış veya tanık olmuş çocukların içselleştirilmiş bozukluklar yaşayabildikleri (kaygı, dikkat dağınıklığı, sosyal geri çekilme, depresyon, intihar düşünceleri), ilgi alanlarına ve sosyal aktivitelere yönelik ilgilerinin azalması, fiziksel saldırganlık ile meşguliyet gösterebildikleri belirtilmiştir. Dolaylı ya da doğrudan şiddet mağduru olan çocukların dişsallaştırıcı bozukluklar yaşayabildikleri (saldırganlık, aşırı hareketlilik/hiperaktivite, davranım bozukluğu), sosyal beceri ve yetkinliklerinin azalması, okul problemleri (devamsızlık, okul başarısının düşmesi), zorbalık, aşırı bağırma, yapışma davranışları, konuşma bozuklukları, yeme bozuklukları) yaşayabildikleri vurgulanmaktadır (KSGM 2009).

Alanyazındaki bu bulgulara ek olarak, Mor Çatı Kadın Sığınağı Vakfı'nın 'Mor Çatı Deneyimi Kadına Yönelik Şiddete Dair Neler Anlatıyor? Kadına Yönelik Şiddet Değerlendirme’ raporunda, kadınların şiddete maruz kaldığı çevrelerde çocukların fiziksel, psikolojik ve cinsel olarak şiddete maruz kalma ihtimalinin, erkek şiddetinin olmadığ 1 çevrelerden daha fazla olduğu vurgulanmıştır. Ek olarak, şiddete uğramış veya tanık olmuş çocukların bir ebeveynin kaybından aşırı korkabildiği, öfke içerikli davranışlar sergileyebildikleri, intikam duygularına sahip olabildikleri, ait olmama duyguları hissedebildikleri, kâbus ile uykularının bölünebildiği, fobilere sahip olabildikleri belirtilmiştir (Sakallı et al. 2017). Bu bilgiye ek olarak, çocukluk döneminde, şiddete maruz kalanların yetişkinlik zamanlarında kişilik bozukluğu veya davranış bozukluğuna sahip olabildikleri tespit edilmektedir. Bu kişilerin ileride kendi çocuklarına daha çok öfke içerikli davranışlar sergiledikleri yapılan araştırmaların bulguları arasındadır (Vahip 
2002; Güleç 2012).

\section{Türkiye'de Kadına Yönelik Şiddetin Önlenmesi Yönünde Gerçekleştirilenler}

Temel insan hakları ihlallerinden birisi olan kadına yönelik şiddet, uluslararası platformda ele alınarak Birleşmiş Milletler (BM) ve Avrupa Birliği (AB) başta olmak üzere farklı uluslararası kuruluşlar tarafından da birtakım düzenlemeler kapsamında geliştirilmiştir. Bu düzenlemelerin amacı, ülkelerin kadına yönelik şiddetin önlenmesine dair birtakım uygulamaları geliştirmektir. Kadının Statüsü Genel Müdürlüğünden edinilen bilgilere göre, uluslararası düzenlemelere; BM İnsan Hakları Evrensel Beyannamesi (1948), BM Kadına Karşı Her Türlü Ayrımcılı̆̆ın Ortadan Kaldırılması Sözleşmesi (CEDAW) 1979/1985, BM Kadınlara Yönelik Şiddetin Ortadan Kaldırılmasına Dair Bildirge (1993), Pekin Deklarasyonu ve Eylem Platformu (1995) ve kadına yönelik şiddet ve aile içi şiddetin önlenmesi ve bunlarla mücadeleye ilişkin Avrupa Konseyi Sözleşmesi(İstanbul Sözleşmesi) (2011/2014) örnek olarak verilebilir (KSGM, 2008). Ulusal mevzuatta ise, Anayasa, Ceza Kanunu, Medeni Kanun, 6284 Sayılı Ailenin Korunması ve Kadına Karşı Şiddetin Önlenmesine Dair Kanun, 5395 Sayılı Çocuk Koruma Kanunu, Kadın Konukevlerinin Açılması ve İşletilmesi Hakkında Yönetmelik, Şiddet Önleme ve İzleme Merkezleri Hakkında Yönetmelik gibi kadın erkek eşitliği ve kadına karşı şiddete yönelik birtakım yasal düzenlemeler mevcuttur (Öztürk et al. 2016). Kadının Statüsü Genel Müdürlügünden elde edilen bilgilere göre, Anayasa'da bulunan "Kanun önünde eşitlik" başliklı 10. Maddeye, "Kadınlar ve erkekler eşit haklara sahiptir. Devlet, bu eşitliğin yaşama geçmesini sağlamakla yükümlüdür. Bu maksatla alınacak tedbirler eşitlik ilkesine aykırı olarak yorumlanamaz." ibaresi de eklenmiştir. Türkiye'de kadın-erkek eşitliğine dayanan ilke; 2001 yılında Anayasa'nın 41. ve 66. maddeleri, 2004 yılında 10. ve 90. maddeleri, 2010 y1lında ise yine 10. maddesinde yapılan değişikliklerle güçlendirilmiştir. Bu bağlamda, Anayasa'nın 10. maddesinin ikinci fikrasında "Kadınlar ve erkekler eşit haklara sahiptir. Devlet, bu eşitliğin yaşama geçmesini sağlamakla yükümlüdür. Bu maksatla alınacak tedbirler eşitlik ilkesine aykırı olarak yorumlanamaz" ibaresine yer verilmiş olup, Anayasanın 41. Maddesi "Aile'de eşitlik ilkesi" de Anayasa' da yerini almıştır. İlaveten, 2002 yılında yürürlüğe giren Yeni Türk Medeni Kanunu kadın/erkek eşitliğini gözeten; cinsiyet ayrımcılığına karşı çıkan; kadınları, aile ve toplum içerisinde erkeklerle eşit kılan bir düzenlemedir. Türk Medeni Kanunu (2002) evlenme yaşını kadınlar ve erkekler için eşitlemiş ve 17 yaşını doldurma şartı getirmiştir (olağanüstü evlenme için 16 yaş). Hiçbir bireyin zorla evlendirilemeyeceği ve aksi takdirde evliliğin iptalinin istenebileceği hükmü mevcuttur. Kadın ve erkek eşitliğini vurgulamak adına, 'Aile Reisliği' kavramı ortadan kaldırılmış ve aile birliğinin idaresinde eşlere eşit söz hakkı verilmiştir. Ek olarak, evin seçimini 'koca'nın yapacağına dair hüküm değiştirilerek, eşlerin yaşayacakları evi beraber seçecekleri hükmü konulmuştur. Türk Ceza Kanunu (2005) ise töre cinayetlerini kasten insan öldürme suçunun nitelikli halleri arasında düzenlemiş, suçlunun ağırlaştırılmış müebbet hapisle cezalandırılacağı hükmünü getirmiştir. Evlilik içerisinde kadının rızası olmadan, kadını cinsel beraberliğe zorlamak tecavüz suçu, işyerinde cinsel tacizi suç olarak ve aynı konutta beraber yaşayan kişilere karşı kötü bir muamelede bulunmayı da suç olarak tanımlamıştır. 5395 Sayılı Çocuk Koruma Kanunu'nun (2005), 1. Maddesi 'Korunma ihtiyacı olan veya suça sürüklenen çocukların korunmasına, haklarının ve esenliklerinin güvence altına alınmasına ilişkin usûl ve esasları düzenlemektir' olarak belirlemiştir. 6284 Sayılı Ailenin Korunması ve Kadına Karşı Şiddetin Önlenmesine Dair Kanun; şiddete uğrayan veya şiddete uğrama tehlikesi bulunan öncelikle kadınlar ve çocukların, aile bireylerinin ve ssrarlı takip mağduru olan bireylerin korunması ve bu bireylere yönelik gerçekleştirilen şiddetin önlenmesi kapsamında alınacak tedbirler kararlarına ilişkin maddeleri düzenler. 6284 sayılı Kanun, şiddet mağdurları ve şiddet uygulayanlar hakkında hâkim/kolluk görevlileri/mülki amirler tarafından, kişinin isteği doğrultusunda veya resen birtakım tedbir kararları çıkartabilir. 6284 Sayılı Ailenin Korunması ve Kadına Karşı 
Şiddetin Önlenmesine Dair Kanuna ilişkin uygulama yönetmeliğinden edinilen bilgilere göre, tedbir kararları koruyucu ve önleyici olmak üzere iki ana başlığa ayrılmaktadır. Koruyucu tedbir kararları şiddete maruz kalanlara yönelik olmakla beraber, önleyici tedbir kararları şiddet uygulayana yöneliktir. Koruyucu tedbir kararları; şiddet mağduru kişiye barınma yerinin sağlanmasını, geçici maddi yardım yapılmasını, iş yerinin değiştirilmesini, kimlik ve ilgili diğer bilgi ve belgelerinin gizlenmesi veya değiştirilmesini kapsamaktadır. Ayrıca, koruyucu tedbir kararının alınabilmesi için şiddetin uygulandığına dair kişiden herhangi bir belge veya darp raporu istenmemektedir. Önleyici tedbir kararları; şiddet mağduruna yönelik olarak şiddet tehdidi, hakaret, aşağılama veya küçük düşürmeyi içeren söz ve davranışlarda bulunmamasını, müşterek konuttan uzaklaştırılması ve müşterek konutun korunan kişiye tahsis edilmesini, korunan kişilerin bulundukları konuta, okula ve işyerine yaklaşmamasını, çocuklarla ilgili kişisel ilişkinin sınırlanması ya da tümüyle kaldırılmasını, alkol ya da uyuşturucu madde bağımlılı̆̆ının olması hâlinde, hastaneye yatmak dâhil, muayene ve tedavisinin sağlanmasını, korunan kişiyi iletişim araçlarıyla veya sair surette rahatsız etmemesini ve bulundurulması veya taşınmasına kanunen izin verilen silahları kolluğa teslim etmesini kapsamaktadır (KSGM 2008).

Kadına yönelik şiddetle mücadele kapsamında, kurumsal mekanizmalar dahilinde Şiddet Önleme ve İzleme Merkezleri (ŞÖNIM), Kadın Konukevleri, Aile Çalışma ve Sosyal Hizmetler Bakanlığı İl Müdürlükleri ve Sosyal Hizmet Merkezleri bulunmaktadır. Şiddet Önleme ve İzleme Merkezlerinde, şiddetin önlenmesi kapsamında koruyucu ve önleyici tedbir kararlarının etkin bir biçimde uygulanmasına yönelik destekleyici rehberlik ve danışmanlık hizmetinin verildiği, psikolojik destek hizmetinin sunulduğu, barınma talebi olan şiddet mağdurları için uygun kadın konukevine yönlendirme işlemlerinin yapıldığı, ilgili personelin (Psikolog, Sosyal Hizmet Uzmanı, Psikolojik Danışman, Sosyolog) görev yaptığı ve tercihen kadın personel istihdam edilmektedir. ŞÖNIM'de verilen hizmet modelleri içerisinde; psiko-sosyal, ekonomik, hukuki, eğitim ve mesleki destek, konukevine yönlendirme, kurumlar arası koordinasyon, müdahale ve yönlendirme çalışmaları bulunmaktadır. Kadının Statüsü Genel Müdürlüğünden edinilen veriye göre, mevcut durumda Türkiye'de 81 İl'de ŞÖNIM hizmeti verilmektedir. Kadın konukevleri; şiddetin türlerinden bir veya birkaçına maruz kalmış kadın ve erkeklerin, şiddetten korunması, psiko-sosyal ve ekonomik sorunlarının çözülmesi, güçlendirilmesi ve bu dönemde varsa çocuklarıyla beraber ihtiyaçlarının da karşılanmak suretiyle en fazla 6 ay süreyle kalabilecekleri, ancak kişinin ihtiyacına göre bu sürenin uzatılabildiği yatılı sosyal hizmet kuruluşlarıdır. Kadın konukevlerine şiddet uygulayanın ulaşmaması ve kadın için risk teşkil edecek durumların meydana gelmemesi adına gizlilik oldukça önemlidir. Bu nedenle kadın konukevlerinin adres bilgileri paylaşılmamaktadır. Aile Çalışma ve Sosyal Hizmetler Bakanlığı İl Müdürlükleri ve Sosyal Hizmet Merkezleri, şiddet mağdurlarına yönelik olarak danışmanlık ve sosyal destek hizmetleri vermektedir (KSGM 2008). İlaveten, şiddet mağduru kadınlar, Valilik veya Kaymakamlıklara, kolluk kuvvetlerine, adli makamlara (Cumhuriyet Başsavcıllı̆ı gibi), Sağlık Kuruluşlarına, ALO 183 Sosyal Destek Hattına, ALO 155 Polis İmdat Hattına, ALO 156 Jandarma İmdat Hattına, Sivil Toplum Kuruluşlarına veya Belediyelere ait Danışma Merkezlerine de başvuruda bulunabilirler. 6284 Sayılı Yasa kapsamında şiddet mağduru kadınlara sunulan hizmet modellerinden biri olan kadın konukevlerinde, kadını güçlendirme kapsamında yapılan çalışmalara rağmen, şiddet mağdurlarının \%40-\%60'ının şiddet uygulayanlara geri döndükleri belirtilmiştir. Ayrıca, kendisine şiddet uygulayan kişiye geri dönen kadınların, dönmeyen kadınlara göre daha düşük benlik saygısına sahip oldukları, bu nedenle bu kadınların içinde bulundukları şiddet döngüsünü kırmak için farkındalık kazanma çalışmaları yapılmalıdır. İlaveten, kadınların kendilerine yönelik inanç ve tutumlarını ve kendileri hakkındaki değerlendirmelerini yükseltmek için destekleyici çalışmalar yapılmasının önemi vurgulanmıştır (Ben-Borat \& Itzhaky 2008). Ek olarak, şiddet mağduru kadınların kadın konukevinden 
ayrılışlarının ardından 6 ay geçtikten sonra, depresyon seviyelerinin arttı̆̆ gözlemlenmiş olup, nedenlerinden birinin kadınların azalan sosyal destekten olumsuz etkilenme olduğu anlaşı1maktadır (Campbell et al. 1995).

\section{Kadına Yönelik Aile İçi Şiddetin Önlenmesi ile İlgili Öneriler}

Aile içi şiddetin olası nedenlerini anlamak konusunda iyi bir model olan "Ekolojik Model" (Heise 1998) düşünüldüğünde, çok fazla risk faktörünün kendi içerisinde etkileşime girerek şiddetin ortaya çıkmasında rol oynadığı bilinmektedir. Bu doğrultuda, aile içi şiddeti önlemek için aynı zamanda hukuki, sosyal, ekonomik ve bireysel vb. gibi birden çok faktöre müdahale de bulunmak gerekebilir. Dünya Sağlık Örgütü'nün (2002) raporunda, aile içi şiddeti önlemek için yapılan girişimler üç başılı altında değerlendirilmektedir. Birincil önlemler, şiddet ortaya çıkmadan önce duruma müdahale etmeyi, ikincil önlemler, şiddetin olduğuna dair ilk ipuçları belirdiğinde şiddetin görülme sıklığını azaltmaya yönelik çaba ve girişimleri, üçüncül önlemler ise şiddetin artık oldukça sık olduğu ve bireye zarar verme haline ulaştığı durumlarda müdahale etmeyi kapsamaktadır. Zara-Page ve İnce'nin (2008) çalışmasında, birincil önlemlere örnek olarak, aile içi şiddet, öfke kontrolü ve çatışma çözme yöntemleri hakkında öğrencileri bilgilendirmek, kamuoyunu aile içi şiddet hakkında bilgilendirmek ve şiddete maruz kalanların başvurabilecekleri mekanizmalar hakkında farkındalıklarını arttırmak adına eğitimsel çalışmalar düzenlemek verilebilir. İkincil önlemler ise, belirli birtakım davranışlarda bulunduğu anlaşılmış (örn., eşine şiddet uygulayan) ya da şiddet açısından risk yaratabilecek özellikleri olan (örn., daha önce eşine şiddet uygulamış olması, flört döneminde kız arkadaşına psikolojik şiddet uygulamış) bireylere yönelik programları kapsamaktadır. Son olarak, üçüncül önlemler kapsamında şiddete maruz kalmış kişilere yardım planlarının belirlenmesini ve şiddet uygulayanın alacakları cezaları konu alan programları kapsamaktadır. Altınay ve Arat'ın (2007) çalışmalarında, şiddet mağduru kadınların sahip olduğu şiddet döngüsünün kırılması adına, medya kanalları veya ders kitapları yoluyla şiddetin bir sorun çözme yöntemi olmadığının anlatılmasının önemini belirtmektedir.

Şiddete uğramış veya şiddete uğrama tehlikesi bulunan kişiler; Cumhuriyet Başsavcılıklarına, Aile Mahkemelerine, Adli Tıp Kurumlarına veya Aile İçi Şiddet Suçları Soruşturma Bürolarına, Sağlık Kurumlarına, Sivil Toplum Kuruluşlarına veya Aile, Çalışma ve Sosyal Hizmetler Bakanlığına bağlı Şiddet Önleme ve İzleme Merkezlerine (ŞÖNIM) ya da ŞÖNIM olmayan İllerde Aile, Çalışma ve Sosyal Hizmetler İl Müdürlüklerine başvuruda bulunabilir, şiddet uygulayan hakkında şikâyette bulunup, önleyici veya koruyucu tedbir kararları ald1rabilirler. Aynı zamanda, şiddet mağdurları hukuki destek almak adına Adli Yardım Bürolarına, Kadın Danışma/Dayanışma Merkezlerine veya Kadın Hakları Kurullarına başvuruda bulunabilirler. Bireyler, şiddete maruz kaldıklarında veya şiddete maruz kalma tehlikeleri yaşadıklarında, haftanın yedi günü yirmi dört saati hizmet veren ALO 183 Sosyal Destek Hattına, ALO 155 Polis İmdat Hattına veya ALO 156 Jandarma Hattına başvuruda bulunma hakkına sahiptir.

Sonuç olarak, kadına yönelik şiddetin önlenmesine dair gerçekleştirilen birincil, ikincil ve üçüncül önlemlere ek olarak, kadınlar ve erkeklerin eşit haklara sahip olduğunun hatırlanması önem arz etmektedir. Sunulan imkân ve haklardan kadınların ve erkeklerin eşit olarak faydalanmalarında her vatandaşın sorumluluğu olduğu bilinmektedir. Şiddete uğrayan kişinin can güvenliği yararının öncelikli olarak gözetilmesi ve şiddet uygulayan hakkında gerekli yaptırımların uygulanabilmesi amacıyla, toplumda yaşayan her bireyin tanık olduğu şiddeti ilgili birimlere ihbar etme sorumluluğu taşımasının gerekliliği vurgulanmaktadır. 


\section{KAYNAKÇA}

Abay E. \& Tuğlu C. (2000). "Şiddet ve Agresyonun Nörobiyolojisi”. Klinik Psikiyatri 3 (2000) 21-26.

Akkaş İ. \& Uyanık Z. (2016). "Kadına Yönelik Şiddet”. Nevşehir Hacı Bektaş Veli Üniversitesi SBE Dergisi 6/1 (2016) 32-42.

Altınay A. G. \& Arat Y. (2007). "Türkiye'de Kadına Yönelik Şiddet Araştırma Raporu”. Tübitak, Ankara 2007.

Attala J. M., Bauza K., Pratt H. \& Vieira D. (1995). "Integrative Review of Effects on Children of Witnessing DomesticViolence". Issues in Comprehensive Pediatric Nursing 18/3 (1995) 163-172.

Bandura A. (1978). "Social Learning Theory of Aggression". Journal of Communication 28/3 (1978) 12-29.

Ben-Porat A. \& Itzhaky H. (2008). "Factors That Influence Life Satisfaction Among Battered Women in Shelters: Those Who Stay Versus Those Who Leave". Journal of Family Violence 23/7 (2008) 597-604.

Bride B. E., Radney M. \& Figley C. R. (2007). "Measuring Compassion Fatigue". Clinical Social Work Journal 35 (2007) 155-163.

Briere J. N. (1992). Child AbuseTrauma: Theory and Treatment of the Lasting Effects. Newbury Park 1992.

Campbell J. \& Humphreys J. (1993). Nursing Care of Survivors of Family Violence. St. Louis 1993.

Campbell J. C. \& Lewandowski L. A. (1997). "Mental and Physical Health Effects of Intimate Partner Violence on Women and Children”. Psychiatric Clinics of North America 20/2 (1997) 353-374.

Campbell R., Sullivan C. M. \& Davidson W. S. (1995). "Women Who Use Domestic Violence Shelters: Changes in Depression Over Time". Psychology of Women Quarterly 19/2 (1995) 237-255.

Can Y. (2014). “Türk Ailesinde Aile İçi Şiddetin Kültürel Dinamikleri”. Turkish Studies 9/8 (2014) 13-19.

Dişsiz M. \& Hotun-Şahin N. (2008). "Evrensel Bir Kadın Sağlığı Sorunu: Kadına Yönelik Şiddet”. Maltepe Üniversitesi Hemşirelik Bilim ve Sanatı Dergisi 1/1 (2008) 50-58.

Dorr A. \& Kovaric P. (1980). "Some People Some of The Time But Which People? Televised Violence and Its Effects". Children and the Faces of Television (1980)183-199.

Dünya Sağlık Örgütü. (2002). Şiddet ve Sağlık Raporu: Özet. Genova 2002.

Eraslan D. \& Kayahan B. (2011). "Şiddetin Nörobiyolojisi”. Türkiye Klinikleri Psychiatry-Special Topics 4/2 (2011) 21-25.

Erden G. \& Akdur S. (2018). “Türkiye’de Kadına Yönelik Aile İçi Şiddet ve Kadın Cinayetleri”. Klinik Psikoloji Dergisi 2/3 (2018) 128-139.

Figley C. R. (2013). Compassion Fatigue: Coping With Secondary Traumatic Stress Disorder in Those Who Treat The Traumatized. Routledge2013.

Geçikli F. \& Geçikli M. (2012). "İş Yerlerinde Mobbing (Psikolojik Şiddet) Sarmalında Kadın: Kamu Üniversitesinde Bir Uygulama”. Uluslararası Katılımlı Kadına ve Çocuğa Karşı Şiddet Sempozyumu (2012) 27-28.

Gökkaya B. V. (2009). “Türkiye'de Şiddetin Kadın Sağlığına Etkileri”. CÜ İktisadi ve İdari Bilimler Dergisi 10/2 (2009) 167-179.

Gökler-Danışman, I. Tarhan-Uçar, C. \& Okay D. (2018). "Eş Şiddeti Nedeniyle Kadın Konukevlerinde Kalmakta Olan Kadınlarda Travma Sonrası Stres ve Travma Sonrası Gelişimin İncelenmesi”. Anadolu Psikiyatri Dergisi 19/6 (2018) 337-344.

Güleç H., Topaloğlu M., Ünsal D. \& Altıntaş M. (2012). “Bir Kısır Döngü Olarak Şiddet”. Psikiyatride Güncel Yaklaşımlar 4/1 (2012) 112-137.

Gürdil-Birinci G. \& Erden G. (2016). "Yardım Çalışanlarında Üstlenilmiş Travma, İkincil Travmatik Stres ve Tükenmişliğin Değerlendirilmesi”. Türk Psikoloji Dergisi 31/77 (2016) 10-26.

Heise L. L. (1998). "Violence Against Women an Integrated: Ecological Framework". Violence Against Women 4/3 (1998) 262-290.

Heise L., Ellsberg M. \& Gottemoeller M. (1999). “Ending Violence Against Women”. Population Reports 27/4 (1999) 1-44.

Hilberman E \& Munson K. (1977). "Sixty Battered Women. Victimology”. An International Journal 3/2 (1977) 460-470.

Holden G. W. \& Ritchie K. L. (1991). "Linking Extreme Marital Discord, Child Rearing, and Child Behavior Problems: Evidence From Battered Women”. Child Development 62/2 (1991) 311-327.

Hughes H. M. (1986). "Research With Children in Shelters: Implications for Clinical Services". Children Today 15/2 (1986) 21-25. 
Jaffe P., Wolfe D. A., Wilson S. \& Zak L. (1986). "Emotional and Physical Health Problems of Battered Women". The Canadian Journal of Psychiatry 31/7 (1986) 625-629.

Janoff-Bulman R. (1985). "The Aftermath of Victimization: Rebuilding Shattered Assumptions". Trauma and Its Wake 1 (1985) 15-35.

Janoff-Bulman R. (1992). Shattered Assumptions: Towards a New Psychology of Trauma. New York 1992.

Kadının Statüsü Genel Müdürlüğ̈̈. (2008). Aile İçi Şiddetle Mücadele El Kitabı. Ankara 2008.

Kadının Statüsü Genel Müdürlüğü. (2013). Kadına Yönelik Şiddetle Mücadele El Kitabı. Ankara 2013.

Karancı A. N., Işıklı S., Aker A. T., Gül E. İ., Erkan B. B., Özkol H. \& Güzel H. Y. (2012). "Personality, Posttraumatic Stress and Trauma Type: Factors Contributing to Posttraumatic Growth and Its Domains in A Turkish Community Sample”. European Journal of Psychotraumatology 3/1 (2012) 1-14.

Kök-Can M. (2010). Sağlık Çalışanının Aile İçi Şiddet Olgusuna Bakış Açısı. Yayımlanmış Yüksek Lisans Tezi. Beykent Üniversitesi, İstanbul 2010.

Lök N., Başoğul C. \& Öncel S. (2016). "Aile İçi Şiddetin Çocuk Üzerindeki Etkileri ve Psikososyal Desteğin Önemi”. Psikiyatride Güncel Yaklaşımlar 8/2 (2016) 155-161.

Maslach C. A. \& Jackson S. A. (1981). "The Measurement of Experienced Burnout". Journal of Occupational Behaviour 2 (1981) 99-113.

Maslach C., Schaufeli W. B. \& Leiter M. P. (2001). "Job Burnout". Annual Review of Psychology 52/1 (2001) 397-423.

McGee C. (2003). Childhood Experiences of DomesticViolence. London 2003.

Newberger E. H., Barkan S. E., Lieberman E. S., McCormick M. C., Yllo K., Gary L. T. \& Schechter S. (1992). "Abuse of Pregnant Women and Adverse Birth Outcome: Current Knowledge and Implications for Practice”. JAMA 267/17 (1992) 2370-2372.

Newell J. M. \& MacNeil G. A. (2010). "Professional Burnout, Vicarious Trauma, Secondary Traumatic Stress, and Compassion Fatigue: A Review of Theoretical Terms, Risk Factors, and Preventive Methods for Clinicians and Researchers". Best Practices in Mental Health 6/2 (2010) 57-67.

Özgentürk İ., Karğın V. \& Baltacı H. (2012). "Aile İçi Şiddet ve Şiddetin Nesilden Nesile İletilmesi”. Polis Bilimleri Dergisi 14/4 (2012) 55-77.

Öztürk Ö., Öztürk Ö. \& Tapan B. (2016). "Kadına Yönelik Şiddetin Kadın ve Toplum Sağlı̆̆ı Üzerine Etkileri”. Sağllk Akademisyenleri Dergisi 3/4 (2016) 139-144.

Rothschild B. \& Rand M. (2006). Help for The Helper, Self-care Strategies for Managing Burnout and Stress: The Psychophysiology of Compassion Fatigue and Vicarious Trauma. New York 2006.

Sakallı A. E., Doğan D., Günel H. \& Güreli Z. (2017). "Mor Çatı Deneyimi Kadına Yönelik Şiddete Dair Neler Anlatıyor? Kadına Yönelik Şiddet Değerlendirme Raporu”. Mor Çatı Kadın Siğınăğ Vakfi (2017) 6-53.

Stewart D. E. \& Robinson G. E. (1998). "A Review of Domestic Violence and Women's Mental Health". Archives of Women's Mental Health 1/2 (1998) 83-89.

Stone A. M. (1992). "The Role of Shame in Post-Traumatic Stress Disorder". American Journal of Ortho Psychiatry 62/1 (1992) 131-136.

Subaşı N. \& Akın A. (2003). "Kadına Yönelik Şiddet; Nedenleri ve Sonuçları". Toplumsal Cinsiyet, Sağllk ve Kadin (2003) 231-249.

Taşdemir-Afşar S. (2016). "Violence Against Women and Femicides in Turkey". European Journal of Multidisciplinary Studies 2 (2016) 70-80.

Vahip I. (2002). "Evdeki Şiddet ve Gelişimsel Boyutu: Farklı Bir Açıdan Bakış". Türk Psikiyatri Dergisi 13 (2002) 312-319.

Yalçın Ö. \& Erdoğan A. (2013). "Şiddet ve Agresyonun Nörobiyolojik, Psikososyal ve Çevresel Nedenleri”. Current Approaches in Psychiatry/Psikiyatride Güncel Yaklasimlar 5/4 (2013) 1-33.

Yaman-Efe Ş. \& Ayaz S. (2010). "Kadına Yönelik Aile İçi Şiddet ve Kadınların Aile İçi Şiddete Bakışı". Anadolu Psikiyatri Dergisi 11/1 (2010) 23-29.

Yanbolluoğlu Ö. (2019). "İkincil Travmatik Stresin Meslek Elemanları Üzerindeki Etkileri: Bir Derleme Çalışması". Uludağ Üniversitesi Fen-Edebiyat Fakültesi Sosyal Bilimler Dergisi 20/36 (2019) 141-164.

Yıldırım A. (1998). Siradan Şiddet: Kadına ve Çocuğa Yönelik Şiddetin Toplumsal Kaynakları. İstanbul 1998.

Zara-Page A. \& İnce M. (2008). “Aile İçi Şiddet Konusunda Bir Derleme”. Türk Psikoloji Yazıları 11/22 (2008) 81-94. 
